\title{
STABILITY INDICATING ULTRA PERFORMANCE LIQUID CHROMATOGRAPHIC ASSAY OF LAMOTRIGINE IN PHARMACEUTICALS
}

\author{
K. B. Vinay ${ }^{1}$, H. D. Revanasiddappa ${ }^{1}$, M. X. Cijo ${ }^{1}$, P. J. Ramesh ${ }^{1}$, N. Swamy ${ }^{1}$, \\ N. Rajendraprasad ${ }^{*}$ \\ ${ }^{1}$ Department of Studies in Chemistry, University of Mysore, Manasagangothri, Mysore, Karnataka, India \\ ${ }^{2}$ PG Department of Chemistry, J.S.S. College, Karnataka, India
}

\begin{abstract}
A simple, precise and accurate stability-indicating isocratic reverse phase ultra-performance liquid chromatographic (RP-UPLC) method was developed for the determination of lamotrigine (LMT) in bulk drug and in its tablets. The method was developed using Waters Aquity BEH $\mathrm{C}_{18}(100 \mathrm{~mm} \times 2.1 \mathrm{~mm}, 1.7$ $\mu \mathrm{m})$ column with mobile phase consisting of a mixture of potassium dihydrogen phosphate buffer of $\mathrm{pH}$ 3.5 and an equal ratio of methanol and acetonitrile $(50: 50 \mathrm{v} / \mathrm{v})$. The eluted compound was detected at 228 $\mathrm{nm}$ with a UV detector. The standard curve of mean peak area versus concentration showed an excellent linearity over a concentration range $1.0-75 \mu \mathrm{g} / \mathrm{mL}$. Within-day and between-days RSD were less than $1.3 \%$ pronounces precision of the method. The accuracy of the method was further ascertained by recovery studies via standard addition procedure and the recoveries obtained were $98-100 \%$. Forced degradation of the bulk sample was conducted in accordance with the ICH guidelines. Acidic, basic, hydrolytic, oxidative, thermal and photolytic degradation were used to assess the stability indicating power of the method. LMT was found to degrade significantly in acidic, basic and oxidative stress conditions and stable in thermal, hydrolytic and photolytic conditions.
\end{abstract}

Key words: Lamotrigine, UPLC, Stability indicating assay, Pharmaceuticals.

\section{INTRODUCTION}

Lamotrigine (LMT), chemically known as [6-(2, 3- dichlorophenyl)-1,2,4-triazine-3,5-diamine] (Figure 1), is a broad spectrum antiepileptic, used as monotherapy and as an adjunct with other antiepileptics for treatment of partial and generalized toxic-clonic seizures. It's use to treat neurological lesions and as a tranquilizer has also been studied [1,2].

Owing to its use as an antiepileptic drug, it has attracted the attention of many analysts. LMT is official in United States Pharmacoepia (USP) [3], which describes a chromatographic technique with monobasic potassium phosphate buffer, triethylamine and acetonitrile as mobile

* Correspondence to: Nagaraju Rajendraprasad ${ }^{b *}$ PG Department of Chemistry, J.S.S. College, Ooty Road, Mysore-570 025, Karnataka, India, email: prasadtnpur@gmail.com phase. The methods for LMT analysis utilized a variety of chromatographic techniques in bodyfluids [4-21]. Most of these chromatographic methods describes assay of LMT either in plasma or serum and few are immunoassays. Few methods have been reported for its determination in pharmaceuticals and include titrimetry with acetous perchloric acid in anhydrous acetic acid medium [22], visible spectrophotometry [23-25], UVspectrophotometry [26, 27], planar chromatography [4], thin layer chromatography and high performance liquid chromatography [28] and adsorptive stripping voltammetry [29]. Simultaneous determination of LMT, oxcarbazepine and zonisamide has been reported by Elizabeth et al [30] using HPLC and gas chromatographic techniques. Recently, Anantha Kumar et al [31] have reported RP-HPLC method in which the assay was carried out on a Luna $\mathrm{C}_{18}$ column by employing a mixture of $\mathrm{KH}_{2} \mathrm{PO}_{4}(\mathrm{pH} 7.3)$ and methanol (60:40) as 
mobile phase and UV detection at $305 \mathrm{~nm}$. The method is reported to be linear over the concentration range $10-70 \mu \mathrm{g} / \mathrm{mL}$ LMT.



Figure 1. Chemical structure of LMT

Ultra performance liquid chromatography (UPLC) is an innovative technique that has brought revolution in liquid chromatography by outperforming conventional HPLC. UPLC decreases sample run times by a factor of 10 , uses up to $95 \%$ less solvent and significantly improves productivity in laboratories. The replacement of standard $5 \mu \mathrm{m}$ particles in conventional HPLC column with sub $2 \mu \mathrm{m}$ particles in UPLC has resulted in significant improvements in resolution, sensitivity and speed in chromatographic separations besides minimizing band spreading contributions of both the instrument column.

UPLC system has been demonstrated to decrease time and cost per analysis significantly besides improving the quality of results with wider linear dynamic range. UPLC photodiode array (PDA) detector detects and quantifies lower levels of analyte and trace impurities at level of $0.004 \%$. It is easy to detect components with UPLC which are difficult by conventional HPLC. In spite of these significant advantages, to the best of our knowledge, a validated RP-UPLC method for the determination of LMT has not been reported.

For LMT so far two UPLC methods are proposed in the literature $[20,21]$ and they are neither applicable for quantification of drug in tablets nor used as routine quality control procedure.

The aim of this work was to develop and validate a sensitive, accurate and precise UPLC method for the determination of LMT in bulk drug and in its tablet dosage form. In addition, the bulk drug was subjected to forced degradation in accordance with the ICH guidelines. Acidic, basic, hydrolytic, oxidative, thermal and photolytic degradation were used to assess the stability indicating power of the method.

\section{EXPERIMENTAL PROCEDURE MATERIALS AND REAGENTS}

Pure active ingredient sample of LMT was kindly supplied by Cipla India Ltd, Mumbai, India, as gift and used as received. Commercial dosage forms used: Lamosyn 100 (Sun pharmaceuticals Ltd, Mumbai, India) and Lametec 50-DT (Cipla India Ltd, Mumbai, India), tablets were purchased from local commercial sources. HPLC grade acetonitrile and methanol were purchased from Merck India Pvt. Ltd. Mumbai, India. Potassium dihydrogen orthophosphate and formic acid were from Qualigens Fine Chemicals. Mumbai, India. Doubly distilled water was used throughout the investigation.

\section{Chromatographic conditions and equipment}

UPLC was performed using a Waters Acquity system equipped with binary solvent delivery pump, an auto sampler and tunable UV (TUV) detector. The output signal was monitored and processed using Empower-2 software. The Chromatographic column used was Acquity UPLC BEH C-18 $(100 \mathrm{~mm}, 2.1 \mathrm{~mm}$ and $1.7 \mu \mathrm{m}$ particle size). Isocratic elution process was adopted throughout the analysis.

\section{Mobile phase preparation}

Dissolved $1.4 \mathrm{~g}$ of potassium dihydrogen orthophosphate in $1000 \mathrm{ml}$ of water and adjusted the $\mathrm{pH}$ to 3.5 using $10 \%$ formic acid. A $600 \mathrm{ml}$ portion of this resulting buffer was mixed with $400 \mathrm{ml}$ of solvent mixture containing equal volumes of methanol and acetonitrile, shaken well and filtered using a $0.22 \mu \mathrm{m}$ Nylon membrane filter. This solution was also used as diluent in all subsequent preparations of the sample.

\section{Instrumental parameters}

The isocratic flow rate of mobile phase was maintained at $0.40 \mathrm{ml} / \mathrm{min}$. The column temperature was adjusted to $35^{\circ} \mathrm{C}$. The injection volume was $4.0 \mu \mathrm{l}$. Eluted compound was monitored at $228 \mathrm{~nm}$ and the run time was 5.0 min. The retention was about $1.9 \mathrm{~min}$.

\section{Procedures \\ Preparation of stock solution}

A stock standard solution of LMT $\left(1 \mathrm{mg} \mathrm{mL}^{-1}\right)$ was prepared by dissolving an accurately 
weighed $100 \mathrm{mg}$ of pure drug in $100 \mathrm{ml}$ volumetric flask using the mobile phase.

\section{Procedure for preparation of calibration curve}

Working solutions containing 1-75 $\mu \mathrm{g} / \mathrm{mL}$ LMT were prepared by serial dilutions of aliquots of the stock solution. Aliquots of $4 \mu \mathrm{L}$ were injected (six injections) and eluted with the mobile phase under the reported chromatographic conditions. The average peak area versus the concentration of LMT in $\mu \mathrm{g} / \mathrm{mL}$ was plotted. Alternatively, the corresponding regression equation was derived using mean peak area-concentration data and the concentration of the unknown was computed from the regression equation.

\section{Preparation of tablet extracts and assay procedure}

Twenty tablets each containing $100 \mathrm{mg}$ or $25 \mathrm{mg}$ of LMT were weighed and transferred into a clean, dry mortar and powdered. Portion of the powdered tablet equivalent to $100 \mathrm{mg}$ of LMT was transferred in to a $100 \mathrm{ml}$ volumetric flask and $60 \mathrm{ml}$ of the mobile phase was added. The content was sonicated for $20 \mathrm{~min}$ to achieve complete dissolution of LMT, and the solution was then diluted to volume with the mobile phase to yield a concentration of $1000 \mu \mathrm{g} / \mathrm{mL}$ and filtered through a $0.22 \mu \mathrm{m}$ nylon membrane filter. The filtrate was then diluted with the mobile phase to get a $50 \mu \mathrm{g} / \mathrm{mL}$ solution. The solution obtained was injected to the UPLC column.

\section{Stress study}

Aliquots of pure drug solution equivalent to 50 $\mu \mathrm{g} / \mathrm{mL}$ LMT were transferred into four different $50 \mathrm{~mL}$ volumetric flasks and added $10 \mathrm{ml}$ of $1 \mathrm{M}$ $\mathrm{HCl}, 1 \mathrm{M} \mathrm{NaOH}$, Water and $5 \% \quad \mathrm{H}_{2} \mathrm{O}_{2}$ separately, and the flasks were heated for $2 \mathrm{~h}$ on a water bath maintained at $80{ }^{\circ} \mathrm{C}$. Then the solutions were cooled and neutralized by adding base or acid, the volume in each flask was brought to the mark with mobile phase, and the required quantity $(4.0 \mu \mathrm{L})$ was injected for analysis. Solid state thermal degradation was carried out by exposing pure drug to dry heat at $105{ }^{\circ} \mathrm{C}$ for $3 \mathrm{~h}$. For photolytic degradation studies, pure drug in solid state was exposed to 1.2 million flux hours in a photo stability chamber. The sample after exposure to heat and light was used to prepare $50 \mu \mathrm{g} / \mathrm{mL}$ solutions in mobile phase and the chromatographic procedure was followed.
PROCEDURE FOR VALIDATION

\section{Accuracy and precision}

To determine the accuracy and intra-day precision, pure LMT solutions at three different concentrations were analyzed in seven replicates during the same day. Mobile phase was injected as blank solution before sample injection and the RSD (\%) values of peak area and retention time were calculated.

\section{Limits of detection (LOD) and quantification (LOQ)}

The LOD and LOQ were obtained by signal to noise $(\mathrm{S} / \mathrm{N})$ ratio method. LOQ and LOD were obtained by a series of dilutions of the LMT stock solution. Precision study was performed at LOQ level also. LOQ solution was injected seven times $(\mathrm{n}=7)$ and calculated the \% RSD values for the obtained peak area and retention time.

\section{Linearity}

Linearity solutions were prepared from LOQ level to $150 \%$ of the actual sample concentration $(50 \mu \mathrm{g} / \mathrm{mL}$ LMT). A total of five concentrations of the solutions $(25,37.5,50,62.5$ and $75 \mu \mathrm{g} / \mathrm{mL}$ levels) were made separately and injected in triplicate.

\section{Robustness and ruggedness}

To determine the robustness of the method the experimental conditions were deliberately changed. The flow rate of the mobile phase $(0.4 \pm 0.04 \mathrm{ml} / \mathrm{min})$, column oven temperature $\left(35 \pm 5{ }^{\circ} \mathrm{C}\right)$, mobile phase composition (66:40, 54:40, 60:36 and 60:44; buffer: solvent mixture $v / v)$ and detection wavelength $(228 \pm 1 \mathrm{~nm})$ were the varied parameters. In each case the \%RSD values were calculated for the obtained peak area and retention time. The number of theoretical plates and tailing factors were compared with those obtained under the optimized conditions. Three different columns of same dimensions were used for the analyses. The study was performed on same day and on three different days by three different analysts for three different concentrations of LMT (triplicates injections). The area obtained from each concentration was compared with that of the optimized one. The relative standard deviation values were evaluated for each concentration.

\section{Solution stability and mobile phase stability}

Stability of LMT solution was performed by injecting the sample into the chromatographic system. The peak area was recorded in the time intervals of 0,12 and $24 \mathrm{hrs}$ and the RSD values were calculated. The mobile phase stability was 
studied by injecting a freshly prepared sample solution at the same time intervals $(0,12$ and 24 hours) and RSD values of the peak areas were calculated.

\section{RESULTS AND DISCUSSION}

\section{Method development}

Different chromatographic conditions were experimented to achieve better efficiency of the chromatographic system. Parameters such as mobile phase composition, wavelength of detection, column, column temperature, $\mathrm{pH}$ of mobile phase and diluents were optimized. Several proportions of buffer, and solvents (water, methanol and acetonitrile) were evaluated in-order to obtain suitable composition of the mobile phase. Choice of retention time, tailing, theoretical plates and run time were the major tasks while developing the method. Alternate combinations of gradient and isocratic methods were also performed to obtain a suitable peak. Finally isocratic method was found better to use for the assay.

When LMT solutions were injected with methanol and acetonitrile solvent mobile phases individually, the resultant peak showed either tailing or much shortened retention time factor. As the buffer ratio increased, peaks eluted with abnormal shape. Acquity BEH C18, $50 \mathrm{~mm} \times$ $2.1 \mathrm{~mm}, 1.7 \mu \mathrm{m}$ column used for the elution, but the peak eluted before 1.5 minutes with a tailing factor of 2. Experiment with Phenyl $100 \mathrm{~mm} \times$ $2.1 \mathrm{~mm}, 2 \mu \mathrm{m}$ column ended with inconsistent retention time and peak fronting. The column temperature was varied from 20 to $45{ }^{\circ} \mathrm{C}$ in a 5 ${ }^{\circ} \mathrm{C}$ increment with the same column, the peak shape was found unaltered. Buffer and methanol: acetonitrile solvents ratio were changed and ended up with less number of theoretical plates. Different buffers like sodium dihydrogen othophospahe, dipotassium hydrogen orthophosphate and disodium hydrogen orthophosphate of different $\mathrm{pH}$ were tried and the results revealed that the use of potassium dihydrogen orthophosphate was most suitable. The $\mathrm{pH}$ of the mobile phase was varied from 2 to 6 . At $\mathrm{pH}$ greater than 3.5 , the peak eluted very early and resulted in less number of theoretical plates. At lower and higher flow rates, no peak elution and inefficiency of the system (pressure $>15000$ psi), respectively, were observed. Under these optimized conditions (40:60 solvent mixture: buffer of $\mathrm{pH} 3.5 \mathrm{v} / \mathrm{v}$, Acquity $\mathrm{BEH}$ $\mathrm{C} 18,100 \mathrm{~mm} \times 2.1 \mathrm{~mm}, 1.7 \mu \mathrm{m}$ column, $35^{\circ} \mathrm{C}$, detection at $228 \mathrm{~nm}$ ) the system was found more suitable for the validation study with the tailing less than 1.2, number of theoretical plates $>2000$ and \% RSD for peak area less than 1.0. The typical chromatograms obtained for blank and pure LMT from final UPLC conditions are depicted in Figure 2.

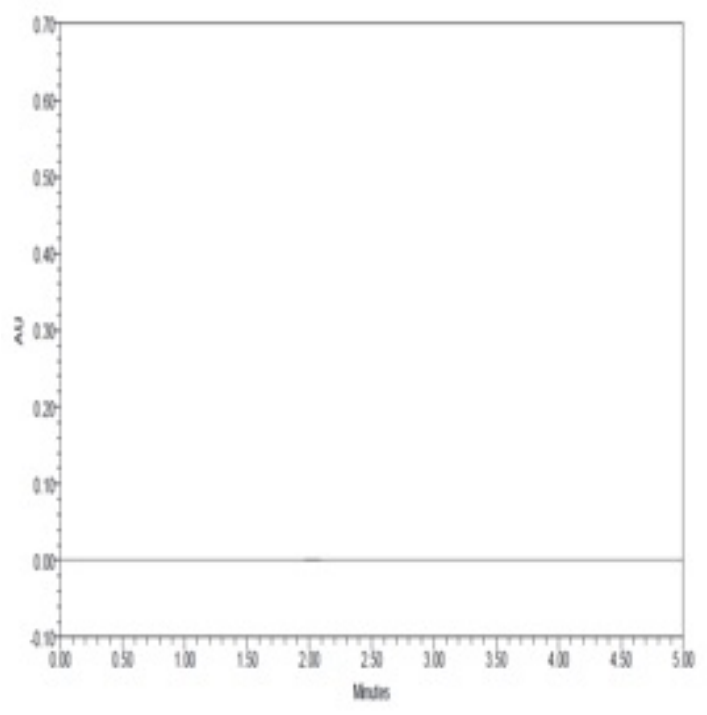

a

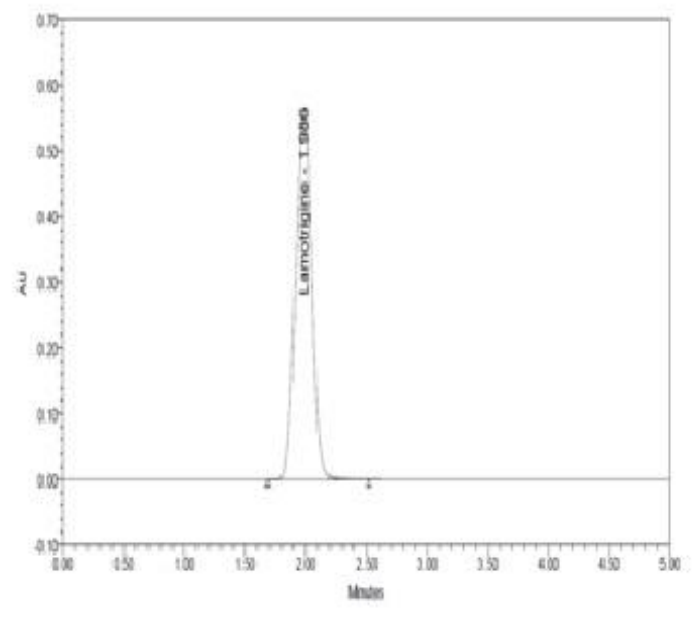

b

Figure 2. Chromatogram obtained for (a) mobile phase blank and (b) pure lamotrigine

\section{Forced degradation}

All forced degradation samples were analyzed at $50 \mu \mathrm{g} / \mathrm{mL}$ concentration level. The observation was made based on the peak area of the respective sample. Degradation was not observed when LMT was subjected to light (1.2 million lux hours), thermal $\left(105^{\circ} \mathrm{C}\right.$ for 3 hours) and hydrolysis (Water) conditions. Significant degradation was observed when the drug was subjected to acid and basic hydrolysis and oxidation $\left(1 \mathrm{~N} \mathrm{HCl}, 1 \mathrm{~N} \mathrm{NaOH}\right.$ and $5 \% \mathrm{H}_{2} \mathrm{O}_{2}$ for 2 hours). The chromatograms obtained for LMT after subjecting to degradation are presented in Figure 3. Assay study was carried out by the comparison with the peak area of LMT sample without degradation. 

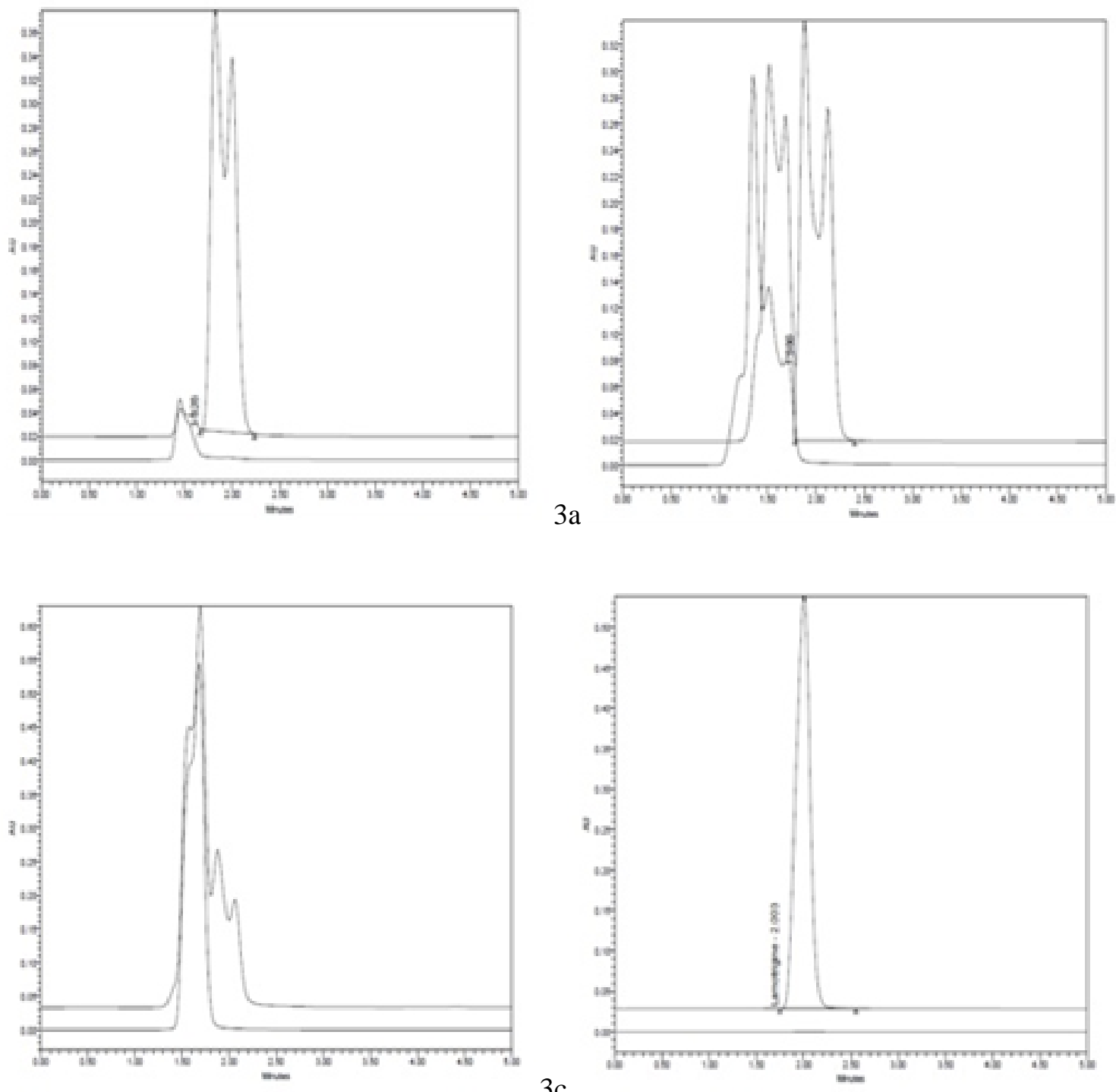

$3 \mathrm{c}$
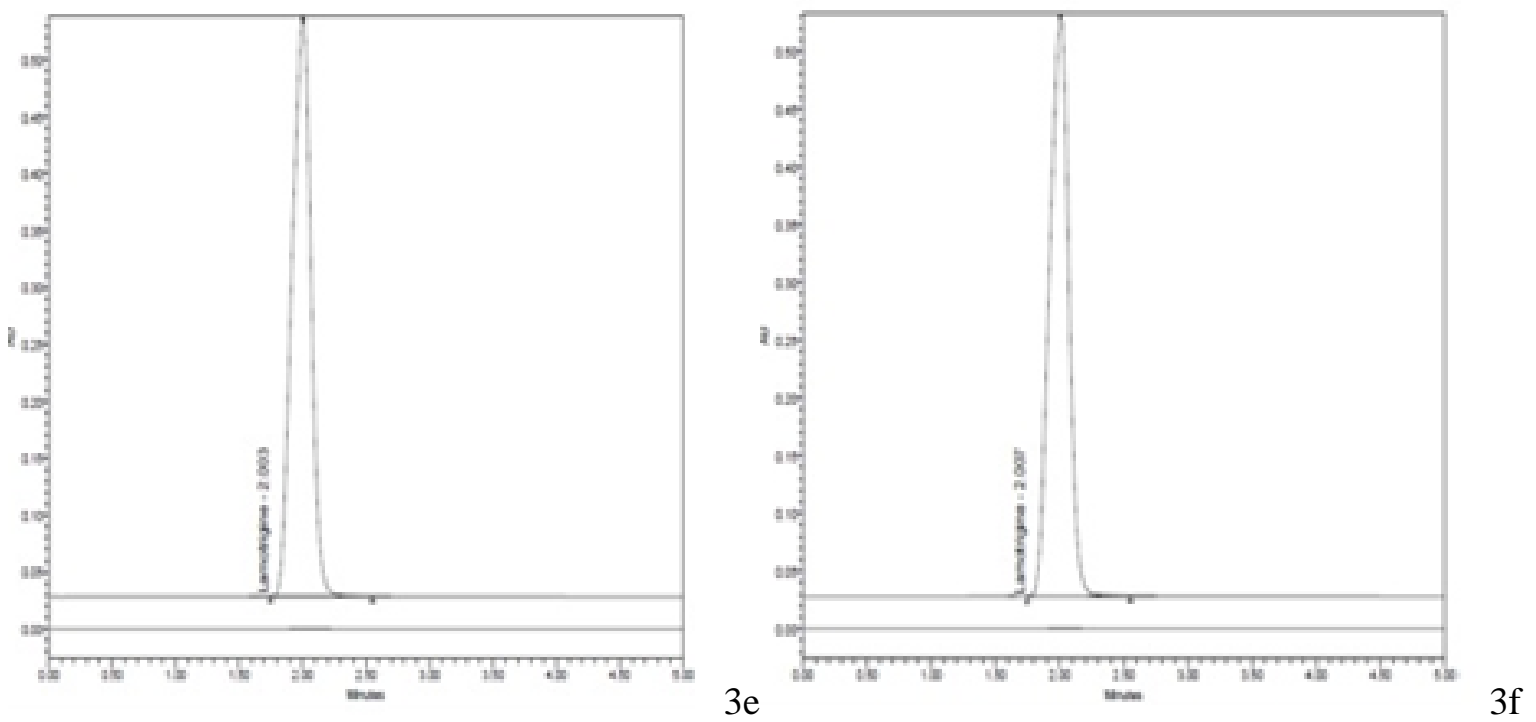

Figure 3. Typical chromatograms obtained for lamotrigine after subjecting to (a) acid, (b) basic, (c) oxidative, (d) hydrolytic, (e) thermal and (f) photo degradation 


\section{VALIDATION OF THE METHOD}

The described method for the assay of LMT has been validated as per the current ICH Q2 (R1) Guidelines [32].

\section{Analytical parameters}

A calibration curve was obtained for LMT from $50 \%$ to $150 \%$ of its stock solution. A linear correlation was obtained between the peak area and the concentration in the range of $1.0-75$ $\mu \mathrm{g} / \mathrm{mL}$ LMT from which the linear regression equation was computed and found to be:

$$
\mathrm{Y}=\mathrm{m} \mathrm{C}+\mathrm{a},(\mathrm{r}=0.9999)
$$

where $\mathrm{Y}$ is the mean peak area, $\mathrm{C}$ is the concentration of LMT in $\mu \mathrm{g} / \mathrm{mL}$ and $\mathrm{r}$ is the correlation coefficient. The LOD and LOQ values, slope (m), y-intercept (a) and their standard deviations are evaluated and presented in Table 1. These results confirm the linear relation between concentration of LMT and the peak areas as well as the sensitivity of the method.

Table 1. Linearity and regression parameters

\begin{tabular}{ll}
\hline Parameter & Value \\
\hline Linear range, $\mu \mathrm{g} / \mathrm{mL}$ & $1.0-75$ \\
Limits of quantification, (LOQ), $\mu \mathrm{g} / \mathrm{mL}$ & 0.10 \\
Limits of detection, (LOD), $\mu \mathrm{g} / \mathrm{mL}$ & 0.03 \\
Regression equation & \\
Slope (b) & 107523.8 \\
Intercept (a) & -55901.9 \\
Correlation coefficient $(\mathrm{r})$ & 0.9999 \\
Standard deviation of $\mathrm{b},\left(\mathrm{S}_{\mathrm{b}}\right)$ & 525.64 \\
Standard deviation of $\mathrm{a},\left(\mathrm{S}_{\mathrm{a}}\right)$ & 25448.51 \\
\hline
\end{tabular}

\section{Accuracy and precision}

The percent relative error which is an index of accuracy is $\leq 1.5$ and is indicative of high accuracy. The calculated percent relative standard deviation (\%RSD) can be considered to be satisfactory. The peak area based and retention time based RSD values were $<1$. The results obtained for the evaluation of precision and accuracy of the method is compiled in Table 2 and 3.

Table 2. Results of accuracy study $(n=7)$

\begin{tabular}{ccccc}
\hline $\begin{array}{c}\text { Concentration of } \\
\text { LMT injected, } \\
\mu \mathrm{g} / \mathrm{mL}\end{array}$ & $\begin{array}{c}\text { Concentration } \\
\text { of LMT found, } \\
\mu \mathrm{g} / \mathrm{mL}\end{array}$ & $\mathrm{RE}^{\mathrm{a}}, \%$ & $\begin{array}{c}\text { Concentration } \\
\text { of LMT found, } \\
\mu \mathrm{g} / \mathrm{mL}\end{array}$ & $\mathrm{RE}^{\mathrm{a}, \%}$ \\
\hline 25 & 24.84 & 0.64 & 24.34 & 2.64 \\
50 & 49.07 & 1.86 & 50.54 & 1.34 \\
75 & 74.68 & 0.43 & 74.19 & 1.08 \\
\hline
\end{tabular}

\footnotetext{
${ }^{a}$ Relative error
} 
VINAY K. B., et al.

Table 3. Results of precision study

\begin{tabular}{|c|c|c|c|c|c|c|c|c|c|}
\hline \multicolumn{2}{|c|}{$\begin{array}{l}\text { Chromatographic } \\
\text { conditions }\end{array}$} & $\begin{array}{l}\text { Mean peak area } \\
\quad \pm \mathrm{SD}^{*}\end{array}$ & $\begin{array}{c}\% \\
\text { RSD }\end{array}$ & Mean $t_{R} \pm S D^{*}$ & $\begin{array}{c}\% \\
\text { RSD }\end{array}$ & $\begin{array}{c}\text { Mean } \\
\text { Theoretical plates } \\
\pm \text { SD* }^{*}\end{array}$ & $\begin{array}{c}\% \\
\text { RSD }\end{array}$ & $\begin{array}{c}\text { Mean } \\
\text { Tailing factor } \\
\pm \mathrm{SD}^{*}\end{array}$ & $\begin{array}{c}\% \\
\mathrm{RSD}\end{array}$ \\
\hline \multirow{3}{*}{ Temperature } & $35^{\circ} \mathrm{C}$ & $5337699 \pm 24019$ & 0.45 & $2.00 \pm 0.002$ & 0.10 & $3824 \pm 48.36$ & 1.72 & $1.10 \pm 0.007$ & 0.64 \\
\hline & $40^{\circ} \mathrm{C}$ & $5229586 \pm 2629$ & 0.05 & $1.98 \pm 0.001$ & 0.05 & $5253 \pm 50.25$ & 2.16 & $1.01 \pm 0.005$ & 0.50 \\
\hline & $45^{\circ} \mathrm{C}$ & $5316145 \pm 12759$ & 0.24 & $1.97 \pm 0.002$ & 0.10 & $4943 \pm 68.98$ & 1.41 & $1.12 \pm 0.006$ & 0.54 \\
\hline \multirow{3}{*}{$\begin{array}{l}\text { Mobile phase } \\
\text { composition }\end{array}$} & 40:60 & $5217656 \pm 8870$ & 0.17 & $2.00 \pm 0.002$ & 0.10 & $5185 \pm 48.36$ & 0.93 & $1.06 \pm 0.007$ & 0.66 \\
\hline & $50: 50$ & $5218928 \pm 8436$ & 0.16 & $1.985 \pm 0.002$ & 0.10 & $5264 \pm 48.36$ & 0.92 & $1.02 \pm 0.003$ & 0.29 \\
\hline & 60:40 & $5316145 \pm 7679$ & 0.14 & $1.97 \pm 0.002$ & 0.10 & $5299 \pm 68.98$ & 1.30 & $1.01 \pm 0.006$ & 0.59 \\
\hline \multirow{3}{*}{$\begin{array}{l}\text { Flow rate } \\
\left(\mathrm{ml} \mathrm{min}^{-1}\right)\end{array}$} & 0.35 & $6176700 \pm 6014$ & 0.10 & $2.00 \pm 0.002$ & 0.10 & $5185 \pm 48.36$ & 0.93 & $1.06 \pm 0.007$ & 0.66 \\
\hline & 0.40 & $5222143 \pm 8594$ & 0.16 & $1.996 \pm 0.002$ & 0.10 & $5174 \pm 60.47$ & 1.17 & $1.04 \pm 0.003$ & 0.29 \\
\hline & 0.45 & $4700348 \pm 7054$ & 0.15 & $1.99 \pm 0.003$ & 0.15 & $5157 \pm 98.57$ & 1.91 & $1.02 \pm 0.008$ & 0.78 \\
\hline \multirow{3}{*}{ Wavelength (nm) } & 226 & $4694298 \pm 3558$ & 0.08 & $1.99 \pm 0.008$ & 0.40 & $5138 \pm 96.48$ & 1.88 & $1.01 \pm 0.001$ & 0.10 \\
\hline & 228 & $5268406 \pm 6674$ & 0.13 & $1.976 \pm 0.002$ & 0.10 & $5118 \pm 56.67$ & 1.11 & $1.01 \pm 0.003$ & 0.30 \\
\hline & 230 & $5113645 \pm 3658$ & 0.07 & $1.99 \pm 0.001$ & 0.05 & $5125 \pm 45.66$ & 0.89 & $1.01 \pm 0.005$ & 0.50 \\
\hline
\end{tabular}

*Mean value of three determinations

\section{Robustness and ruggedness}

The robustness of an analytical procedure is a measure of its capacity to remain unaffected by small, but deliberate variations in method parameters and provides an indication of its reliability during normal usage. At the deliberate varied chromatographic conditions (flow rate, temperature, and mobile phase composition), the analyte peak \%RSD, tailing factor and theoretical plates remained near to the actual values. The RSD values ranged from 0.1 to $1.2 \%$ resumes the robustness of the proposed method. In method ruggedness, different columns (same lot), at different day by different analyst were performed. The results were summarized in Table 4 and 5.

\section{Stability of the solution}

At the specified time interval, \% RSD for the peak area obtained from drug solution stability and mobile phase stability were within $1 \%$. This shows no significant change in the elution of the peak and its system suitability criteria (\%RSD, tailing factor, theoretical plates). The results also confirmed that the standard solution of drug and mobile phase were stable at least for 24 hours during the assay performance.

Table 4. Method robustness

\begin{tabular}{clllllc}
\hline $\begin{array}{c}\text { Concentration } \\
\text { injected } \\
\mu \mathrm{g} / \mathrm{mL}\end{array}$ & \multicolumn{3}{c}{ Intra-day precision $(\mathrm{n}=7)$} & \multicolumn{2}{c}{ Inter-day precision $(\mathrm{n}=5)$} \\
\cline { 2 - 7 } & Mean area $\pm \mathrm{SD}$ & $\begin{array}{l}\text { RSD } \\
\%^{\mathrm{a}}\end{array}$ & $\begin{array}{l}\text { RSD } \\
\%^{\mathrm{b}}\end{array}$ & Mean area $\pm \mathrm{SD}$ & RSD\% $^{\mathrm{a}}$ & RSD\% $^{\mathrm{b}}$ \\
\hline 25 & $2706422 \pm 1246$ & 0.38 & 0.38 & $2697635 \pm 1284$ & 0.32 & 0.56 \\
50 & $5344217 \pm 1923$ & 0.76 & 0.45 & $5339877 \pm 6767$ & 0.24 & 0.54 \\
75 & $8073493 \pm 1445$ & 0.47 & 0.37 & $8076876 \pm 3786$ & 0.67 & 0.64 \\
\hline
\end{tabular}

\footnotetext{
${ }^{a}$ Relative standard deviation based on peak area

${ }^{\mathrm{b}}$ Relative standard deviation based on retention time
} 
VINAY K. B., et al.

Table 5. Method ruggedness

\begin{tabular}{ccccccccc}
\hline Variable & $\begin{array}{c}\text { Mean Peak area } \\
\pm \text { SD* }\end{array}$ & RSD\% & $\begin{array}{c}\text { Mean } t_{\mathrm{R}} \pm \\
\mathrm{SD}^{*}\end{array}$ & $\mathrm{RSD} \%$ & $\begin{array}{c}\text { Mean } \\
\text { plates } \pm \mathrm{SD}\end{array}$ & $\mathrm{RSD} \%$ & $\begin{array}{c}\text { Mean Tailing } \\
\text { factor } \pm \text { SD* }\end{array}$ & RSD \\
\hline $\begin{array}{c}\text { Analyst } \\
(\mathrm{n}=3)\end{array}$ & $5271157 \pm 6714$ & 0.13 & $1.996 \pm 0.002$ & 0.11 & $5416 \pm 70.63$ & 1.30 & $1.11 \pm 0.004$ & 0.36 \\
\hline $\begin{array}{c}\text { Column } \\
(\mathrm{n}=3)\end{array}$ & $5282015 \pm 6318$ & 0.12 & $1.995 \pm 0.003$ & 0.15 & $5388 \pm 86.33$ & 1.60 & $1.08 \pm 0.005$ & 0.46 \\
\hline
\end{tabular}

*Mean value of three determinations

\section{Selectivity}

Selectivity of the method was evaluated by injecting the mobile phase, placebo blank, pure drug solution and tablet extract. No peaks were

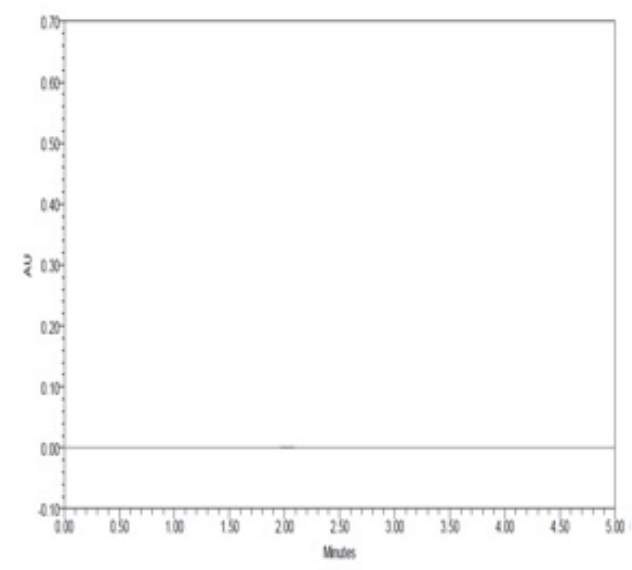

4a

observed for mobile phase and placebo blank and no extra peaks were observed for tablet extracts (Figures $4 a$ and $4 b$ ).

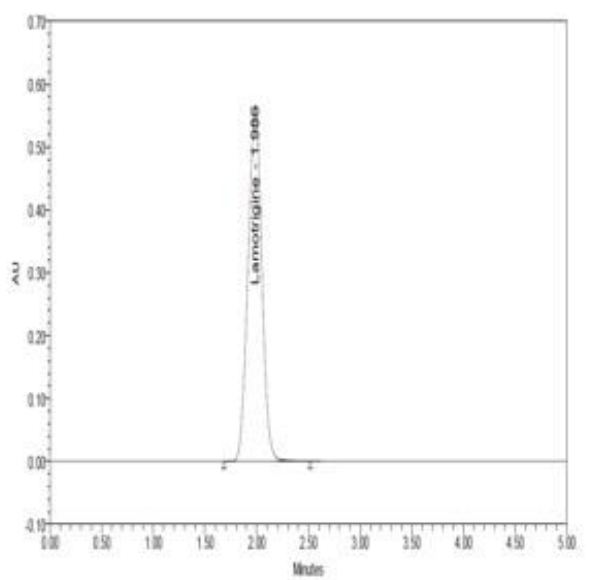

Figure 4. Typical chromatogram obtained for (a) placebo blank (b) tablet extract

\section{Application to tablet}

A $50 \mu \mathrm{g} / \mathrm{mL}$ solution of tablets was prepared as per 'preparation of tablet extracts and assay procedure' and injected in triplicate to the UPLC system. The mean peak area of the tablets extract was found to be equivalent to the pure drug and the results were compared with those of a reference method [3]. The reference method involved a chromatographic technique with monobasic potassium phosphate buffer, triethylamine and acetonitrile as mobile phase.The accuracy and precision of the proposed method was further evaluated by applying Student's t- test and variance ratio Ftest, respectively. The $\mathrm{t}-$ and $\mathrm{F}-$ values at $95 \%$ confidence level did not exceed the tabulated values and this further confirms that there is no significant difference between the reference and proposed methods. Table 6 illustrates the results obtained from this study.

Table 6. Results of analysis of tablets by the proposed methods and statistical comparison of the results with the reference method

\begin{tabular}{cccccc}
\hline \multirow{2}{*}{$\begin{array}{c}\text { Formulation brand } \\
\text { name }\end{array}$} & $\begin{array}{c}\text { Nominal } \\
\text { amount, mg }\end{array}$ & \multicolumn{2}{c}{ \% LMT found ${ }^{\mathrm{c}} \pm \mathrm{SD}$} & \multirow{2}{*}{ t- value } & \multirow{2}{*}{ F- value } \\
\cline { 2 - 4 } & 100.0 & Reference method & Proposed method & & \\
\hline Lamosyn $100^{\mathrm{a}}$ & 25.0 & $100.8 \pm 0.68$ & $99.86 \pm 0.52$ & 2.45 & 1.71 \\
Lametec 25 & $\mathrm{b}$ & $100.6 \pm 0.72$ & $99.65 \pm 0.86$ & 2.21 & 1.42 \\
\hline
\end{tabular}

\footnotetext{
${ }^{a}$ Marketed by Sun pharmaceuticals Ltd, Mumbai, India

${ }^{\mathrm{b}}$ Cipla India Ltd, Mumbai, India

${ }^{\mathrm{c}}$ Mean value of five determinations. Tabulated t-value at $95 \%$ confidence level is 2.78; Tabulated F-value at $95 \%$ confidence level is 6.39
} 
VINAY K. B., et al.

\section{Recovery study}

A standard addition procedure was followed to further evaluate the accuracy of the method. The solutions were prepared by spiking pure drug into a pre-analyzed tablet powder at three different levels and injected to chromatographic column. The recovery of the known amount of added analyte was computed. The percentage recovery of LMT from pharmaceutical dosage forms ranged from $99.49 \%-101.4 \%$. The results given in Table 7 reveal good accuracy of the proposed method.

Table 7. Results of recovery study by standard addition method

\begin{tabular}{ccccc}
\hline Tablet studied & $\begin{array}{c}\text { LMT in tablet, } \\
\mu \mathrm{g} / \mathrm{mL}\end{array}$ & $\begin{array}{c}\text { Pure LMT, } \\
\mu \mathrm{g} / \mathrm{mL}\end{array}$ & $\begin{array}{c}\text { Total found, } \\
\mu \mathrm{g} / \mathrm{mL}\end{array}$ & $\begin{array}{c}\text { Pure LMT } \\
\text { recovered } \\
\% \pm \mathrm{SD}\end{array}$ \\
\hline \multirow{3}{*}{ Lamosyn 100} & 29.96 & 15.0 & 45.59 & $97.56 \pm 0.68$ \\
& 29.96 & 30.0 & 60.05 & $100.3 \pm 0.86$ \\
& 29.96 & 45.0 & 76.13 & $102.6 \pm 0.58$ \\
\hline \multirow{2}{*}{ Lametec 25} & 29.59 & 15.0 & 44.77 & $101.4 \pm 0.80$ \\
& 29.59 & 30.0 & 60.85 & $104.2 \pm 0.57$ \\
& 29.59 & 45.0 & 74.87 & $100.7 \pm 0.66$ \\
\hline
\end{tabular}

\section{CONCLUSIONS}

A rapid isocratic RP-UPLC method was developed for quantitative analysis of lamotrigine in pharmaceutical dosage forms is precise, accurate, linear, robust and specific. Satisfactory results were obtained from validation of the method. The retention time obtained (1.9 $\mathrm{min}$ ) enables rapid determination of the drug which is important in routine analysis. The method exhibited an excellent performance in terms of sensitivity and speed. The method is stability indicating and can be used for routine analysis of production samples and can be used for the assay of lamotrigine either in pure drug or pharmaceutical formulations. Degradation study of the method reveals that the product is highly unstable in acidic, basic and oxidative media and stable in hydrolytic, photolytic and elevated temperature.

\section{ACKNOWLEDGEMENT}

Authors are thankful to the University of Mysore for providing the permission and facilities to do research work. Three of the authors (KBV, CMX \& PJR) are grateful to Jubilant Life Science, Nanjangud, Mysore, for permission to pursue Ph.D programme. The author NRP is very thankful to authorities of J.S.S.M.V.P for providing the platform to continue the research.

\section{REFERENCES}

1. Gilman, A. G., Hardman, J. G. and Limbird, L. E., "Goodman and Gilman's the Pharmacological Basis of Therapeutics." 10th ed. McGraw Hill. New York, U.S.A, pp. 539, 2001.

2. Sean, C. and Sweetman. Martindale: The Complete Drug Reference 34th ed. Pharmaceutical Press. London, pp. 363, 2005.

3. The United States Pharmacopoeia, XXIV rev, National Formulary XIX Rockville, USP Convention, USA, 2000.

4. Dreassi, E., Corbini, G, P., Corti, M., Ulivelli. and Rocchi, R. Quantitative analysis of lamotrigine in plasma and tablets by planar chromatography and comparison with liquid chromatography and UV spectrophotometry. J AOAC International, 79: 1277-1280, 1996.

5. Contin, M., Balboni, M., Callegati, E., Candela, C., Albani, F., Riva, R. and Baruzzi, A. Simultaneous liquid chromatographic determination of lamotrigine, oxcarbazepine monohydroxy derivative and felbamate in plasma of patients with epilepsy. J Chromatogr B, 828: 113-117, 2005.

6. Sean, R. and Mark, S. L. Determination of lamotrigine in biologic materials by a simple and rapid liquid chromatographic method. Ther Drug Monit, 20: 209-214, 1998.

7. Matar, K. M., Nicholls, P. J., Tekle, A., Bawazir, S. A., Al-Hassan. and Mohammed, I. Liquid chromatographic determination of six antiepileptic drugs and two metabolites in microsamples of human plasma. Ther Drug Monit, 21: 559-564, 1999. 
VINAY K. B., et al.

8. Ching-Ling, C., Chen-His, C. and Yoa-Pu $\mathrm{Hu}, \mathrm{O}$. Determination of lamotrigine in small volumes of plasma by high-performance liquid chromatography. $J$ Chromatogr $B$, 817: 199-206, 2005.

9. Matar, K. M., Nicholls, P. J., Tekle, A., Bawazir, S. A. and Al-Hassan. A rapid liquid chromatographic method for the determination of lamotrigine in plasma. $J$ Pharm Biomed Anal, 17: 525-531, 1998.

10. Londero, D. and Lo Greco, P. New micro method for the determination of lamotrigine in human plasma by highperformance thinlayer chromatography. $J$ Chromatogr $B$ Biomed Sci App, 691: 139-144, 1997.

11. Elizabeth, G-S., Giannoutsos, S., Lower, D R., Virji, M A. and Krasowski, M D. Drug monitoring: simultaneous analysis of lamotrigine, oxcarbazepine, 10hydroxycarbazepine, and zonisamide by HPLC-UV and a rapid GC method using a nitrogen-phosphorus detector for levetiracetam. J Chromatogr Sci, 45: 616622, 2007.

12. Patil, K M. and Bodhankar, S L. Simultaneous determination of lamotrigine, phenobarbitone, carbamazepine and phenytoin in human serum by highperformance liquid chromatography. $J$ Pharm Biomed Anal, 39: 181-186, 2005.

13. Saracino, M., Koukopoulos, A., Sani, G., Amore, M. and Raggi, M A. Simultaneous high-performance liquid chromatographic determination of olanzapine and lamotrigine in plasma of bipolar patients. Ther Drug Monit, 29: 773-780, 2007.

14. Bartoli, A., Marchiselli, R. and Gatti, G. A Rapid and specific assay for the determination of lamotrigine in human plasma by normal-phase HPLC. Ther Drug Monit, 19: 100-107, 1997.

15. Cociglio, M., Alric, R. and Bouvier, O. Performance analysis of reversed-phase liquid chromatographic assay of lamotrigine in plasma using solvent-demixing extraction. J Chromatogr B Biomed Sci App, 110: 269276, 1991.

16. Lensmeyer, G.L., Gidal, B.E. and Wiebe, D.A. Optimized high-performance liquid chromatographic method for determination of lamotrigine in serum with concomitant determination of phenytoin, carbamazepine, and carbamazepine epoxide. Ther Drug Monit, 19: 292-300, 1997.
17. Angelis-Stoforidis, P., Morgan, D.J., O'Brien, T.J. and Vajda, F.J.E. Determination of lamotrigine in human plasma by high-performance liquid chromatography. J Chromatogr B Biomed Sci Appl, 727: 113-118, 1999.

18. Croci, D., Salmaggi, A., de Grazia, U. and Bernardi, G. New high-performance liquid chromatographic method for plasma/serum analysis of lamotrigine, Ther Drug Monit, 23: 665-668, 2001.

19. Castel-Branco, M,M., Almeida, A.M., Falcao, A.C., Macedo, T.A., Caramona, M.M. and Lopez, F.G. Lamotrigine analysis in blood and brain by high-performance liquid chromatography, $J$ Pharm Biomed Anal, 755: 119-127, 2001.

20. Juenke, J.M., Miller, K.A., Ford, M.A., McMillin, G.A., Johnson-Davis, K.L. A comparison of two FDA approved lamotrigine immunoassays with ultra-high performance liquid chromatography tandem mass spectrometry. Clin Chim Acta, 412, 1879-1882, 2011.

21. Marcelín-Jiménez, G., P Angeles Moreno, A.C., Mendoza-Morales, L., RiveraEspinosa, L., Martínez, M.M. Development of an ultra-performance liquid chromatography-tandem mass spectrometry micromethod for quantification of lamotrigine in human plasma and its use in a bioequivalence trial. Bioanalysis, 1, 47-55, 2009.

22. Rajendraprasad, N., Basavaiah, K. and Vinay, K.B. Determination of drug content of pharmaceuticals containing Lamotrigine by titrimetry in non-aqueous medium. Proc Indian Nat Sci Acad, 75: 131-136, 2009.

23. Rajendraprasad, N., Basavaiah, K. and Vinay, K.B. Sensitive spectrophotometric determination of lamotrigine in bulk drug and pharmaceutical formulations using bromocresol green. Ecletica Quimica, 35: 55-66, 2010.

24. Rajendraprasad, N., Basavaiah, K. and Vinay, K. B. Micro and nanogram determination of lamotrigine in pharmaceuticals by visible spectrophotometry using bromophenol blue. Indian J Chem Tech, 17: 220-228, 2010.

25. Alizadeh, N., Khakinahad, R. and Jabbari, A. Spectrophotometric determination of lamotrigine in pharmaceutical and urine by charge-transfer complexation. Pharmazie, 63: 791-795, 2008. 
VINAY K. B., et al.

26. Talekar, R S., Dhake, A S., Sonaje, D B. and Mourya, V K. Spectrophotometric determination of lamotrigine. Indian $J$ Pharm Sci, 62: 51-52, 2000.

27. N. Rajendraprasad, K. Basavaiah, K.B. Vinay, P.J. Ramesh. Simple and sensitive spectrophotmetric determination of lamotrigine in pure form and in dosage forms. Pharm Anal Acta, 3: 188-194, 2013.

28. Youssef, N F. and Taha, E A. Development and validation of spectrophotometric, TLC and HPLC methods for the determination of lamotrigine in presence of its impurity. Chem Pharm Bull, 55: 541-545, 2007.

29. Olga, D-R., Calvo, M E. and AcrosMartinez, M J. Determination of lamotrigine in pharmaceutical preparations by adsorptive stripping voltammetry using screen printed electrodes, Sensors, 8: 4201-4212, 2008.

30. Elizabeth, G-S., Giannoutsos, S., Lower, D R., Virji, M A. and Krasowsk,i M D. Drug monitoring: simultaneous analysis of lamotrigine, oxcarbazepine, 10hydroxycarbazepine, and zonisamide by HPLC-UV and a rapid GC method using a nitrogen-phosphorus detector for levetiracetam. J Chromatogr Sci, 45: 616622, 2007.

31. Anantha Kumar, D., Venkatakumar, C., Seetharamaiah, P. and Sheshagiri Rao, J.V.L.N. Estimation of lamotrigine by RPHPLC method. E-J Chem, 7: 5203-5208, 2010.

32. International Conference on Hormonisation of Technical Requirements for Registration of Pharmaceuticals for Human Use, ICH Harmonised Tripartite Guideline, Validation of Analytical Procedures: Text and Methodology Q2(R 1), Complementary Guideline on Methodology dated 06 November 1996, incorporated in November 2005, London. 